\title{
Influence of Demographic Factors on Job Satisfaction of University Faculties in Nepal
}

\author{
Indira Shrestha \\ Lecturer \\ Nepal Commerce Campus, Faculty of Management, T.U.
}

\begin{abstract}
This study is intended to examine the influence of demographic factors on job satisfaction of university faculties. One hundred and six faculty members teaching areas of management in central department of Tribhuvan University and its constituent campuses were taken as the sample. The study used survey questionnaire (23 items) derived from long form Minnesota Satisfaction Questionnaire (MSQ) (1967). The statistical tools like independent sample t-test and ANOVA were applied to find the result. The result revealed that among eight demographic variables, monthly income seemed more important variable which had significant influence on six variables (social recognition, working environment, compensation, promotion recognition and union) of job satisfaction. Furthermore, designation seemed second important demographic variable which had significant influence on five variables of job satisfaction of faculty members. Limitations of the study are identified and recommendation for the future researchers are discussed.
\end{abstract}

Key words: job satisfaction, demographic factors, university faculties.

\section{Introduction}

Lecturer perform several important functions to address a prevailing problem or to exploit opportunities in the society (Awang, Hanim \& Mohammad 2010). In any kind of organizations, situation of human resource management always plays crucial role to succeed. We all know that human resource is asset of organizations because it is important factor of production and no one organization can succeed although these organizations are financially, technologically sound until and unless human resources are satisfied. So this kind of research has been conducted in the areas of job satisfaction in national and international area. In educational organizations, it is imperative to conduct research because quality of education in universities has been associated with job satisfaction of faculty members of university. Considering all those things this study has focused on the demographic factors that influence job satisfaction of faculty members of central department of management of Tribhuvan University (T.U) and its constituent campuses. Tribhuvan University which was established in 1959 is the first national institution of higher education in Nepal. The central administrative office and the central campus of the university are located on the north eastern façade of Kirtipur. The main objective of TU is to prepare capable human resource required for the overall development of Nepal (Tribhuvan University, 2018).

Jorf, Yaccob, and Shah (2011) define job satisfaction as employee's positive or negative feeling towards his or her job. If employees have positive feeling towards job they are satisfied and if they have negative feeling towards their job, they are dissatisfied.

\section{Review of Literature}

Josias (2005) argues that most of the employees give priority to social recognition. In an academic 
field, social recognition could be considered as the judgment, which is provided to an academic for being a valued individual of his/her educational institution and society.

Paul and Phua (2011) found that demographic variables like job position and age (except academic qualification, gender, marital status, and length of employment) have influence on level of job satisfaction.

Zarafshani and Alibaygi (2008) studied the overall level of job satisfaction of faculty engaged in Razi University in Iran using modified version of the Minnesota Satisfaction Questionnaire (MSQ) to receive information from 128 faculty members and the result revealed that number of publication and tenure have significant influence on overall job satisfaction of faculty members.

Amarasena, Ajward, and Haque (2015) found that social recognition is highly significant positive factor to affect the job satisfaction of faculty members in Sri Lanka.

Many research studies have indicated that several factors (like work content, financial reward, promotion, workload, co-workers) contribute to the job satisfaction among academic staff members (Saane et al. 2003).

Amarasena et al. (2015) found that job position and monthly salary (except teaching experience, gender, age, highest level of education, marital status and number of children of staff members) do not have influence on job satisfaction.

Milledzi, Amponsah, and Asamani (2018) found that age and marital status have influence on job satisfaction among academic staff of university in Ghana.

\section{Determinants of job satisfaction}

Social recognition

According to Josias (2005) being recognized in their respective work places, almost all employees place a high importance on such recognition.

\section{Promotion}

Sseganga and Garrett (2005) found that factor such as, promotion, has a strong relationship with job satisfaction of faculty members in the context of Uganda.

Kaliski (2007) explained that worker's sense of work fulfilment come from promotion is a function of job satisfaction.

\section{Working environment}

Zainudin et al. (2010) and Danish and Usman (2010) found positive significant relationship between working environment and job satisfaction.

Vandenberghe and Trembley (2008) argue that job satisfaction is a result of various factors in the working environment.

\section{Compensation}

Strydom (2011) found that remuneration plays a vital role in job satisfaction and dissatisfaction of university academic staff members.

\section{Recognition}

Kaliski (2007) indicates that job satisfaction could be considered as the important factor that help in recognition and the achievement of other goals leading to a sense of fulfillment.

\section{Union}

When job attributes are controlled, unionization has a significant positive effect on satisfaction (Pfeffer \& Davis, 1990). Asamani and Menesh (2013) found that union members are more satisfied in their jobs than nonunion members. 
Vol. 4, No. 1

\section{Conceptual Framework}

Based on the literature review, the study proposes the following conceptual framework.

Independent variables

\begin{tabular}{|l|}
\hline i) Social recognition \\
ii) working environment \\
iii) Compensation \\
iv) Recognition \\
v) Promotion \\
vi) Union \\
\hline
\end{tabular}

Dependent variable

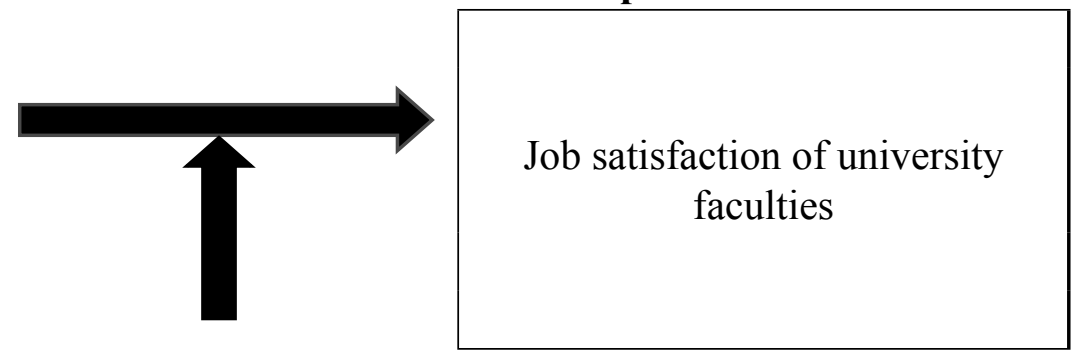

Moderating variables

(Gender, designation, service year, education, age, income, service type and types of college)

Figure 1. Schematic diagram of conceptual framework

\section{Statement of the problem}

Job satisfaction of human resource have been emerging issues not only in business organizations but also in educational institutions. Most of the research related to factors that affect job satisfaction have been conducting in business arena but less in educational institutions. Most of the work as stated in previous section has been conducted in different part of the world except Nepal and their results might not be generalized within the educational institutions among different countries. There exists a potential gap in adopting the results of these researches on the demographic factors that influence job satisfaction of university faculties in the context of Nepal. This research therefore aims to provide empirical evidence of examining the demographic factors that influence the job satisfaction among the faculty members of university in Nepal. The outcomes of the research studies regarding demographic factors influencing job satisfaction are not unanimous so the study on this area in the context of university faculties is assumed invaluable. The major issues of faculties of Tribhuvan University regarding job satisfaction have been found and which are given below:

- Is there any influence of demographic variables (gender, designation, service year, education, age, income, service type and types of college) on job satisfaction of faculty members of central department of management, T.U and its constituent campus?

\section{Objectives of the study}

The objective of the study is to analyze the influence of demographic variables (Gender, designation, service year, education, age, income, service type and types of college) on job satisfaction of faculty members of central department of management, T.U and its constituent campus.

\section{Research Methodology}

Structured questionnaire has been used to collect the data from respondents. Moreover, this study has analyzed the influence of demographic variables (gender, designation, service year, education, age, income, service type and types of college) on job satisfaction (dependent variable) among faculty members of department of management TU and its constituent campuses employing analytical research design. This study is based on primary data collected through well-framed structured questionnaires to elicit the wellconsidered opinions of the faculty members of central department of management of TU and its constituent campuses. Population for this study is faculty members (who teaches areas of management only) of central department of management TU and its constituent colleges situated in Kathmandu, Bhaktapur, and Lalitpur $\sim 61 \sim$ 
districts. Sample size for this study is 106. Simple random sampling has been employed to select the sample. To measure job satisfaction, (23 items related to social recognition, promotion, compensation, recognition, working environment) have been adapted from long form Minnesota Satisfaction Questionnaire (MSQ) (1967). This study has been conducted in the area of educational institutions, so some questionnaires of job satisfaction have been modified to fit in the context of educational institutions. Pfeffer and Davis (1990) argued that when job attributes are controlled, unionism has a significant positive effect on satisfaction. Asmami and Menash (2013) found that union members are more satisfied in their job than non-union members. Based on this argument researcher has developed 4 items related to teacher's union of T.U. Minnesota Satisfaction Questionnaire (MSQ) was measured on a Likert's 5 points scale ranging from Strongly Agree (5), to Strongly Disagree (1). Questionnaires for job satisfaction used in this study has been developed and validated by Vocational Psychology Research, University of Minnesota (1967). For reliability test of JS, Cronbach $\alpha$ coefficient was calculated. Cronbach $\alpha$ coefficient for JS (items 23) were 0.941 . Cronbach alpha coefficient for scales like social recognition -3 items $(\alpha=0.779)$, working environment- 6 items $(\alpha=0.831)$, compensation- 5 items $(\alpha=0.885)$ and recognition- 3 items $(\alpha=0.872)$, promotion- 2 items $(\alpha=0.785)$, and union- 4 items $(\alpha=0.928)$. As indicated, the Cronbach alpha coefficients for all multi-item scales exceed the 0.70 levels as recommended by (Nunnally $\&$ Bernstein, 1994).

As indicated above, this study has applied quantitative analytical techniques to describe, analyze the influence of demographic variables on job satisfaction of faculty members. For the analysis of this study, statistical tools like, frequency, percentage, One-way ANOVA and independent sample t- test have been proposed and used in describing and analyzing the sampled data.

\section{Data Analysis}

In this section to analyze quantitative data, demographic analysis has been conducted by using frequency and percentage. In the same way ANOVA-test and independent sample t-test have been used for testing the influence of demographic variables on job satisfaction. 
Vol. 4, No. 1

\section{Descriptive analysis}

Table 1: Social-demographic profiles of respondents

\begin{tabular}{|c|c|c|c|}
\hline Personality & & Respondent & Percentage $(\%)$ \\
\hline \multirow{3}{*}{ Gender } & Male & 104 & 98.1 \\
\hline & Female & 2 & 1.9 \\
\hline & Total & 106 & 100 \\
\hline \multirow{5}{*}{ Marital Status } & Married & 105 & 99.1 \\
\hline & Unmarried & 1 & 0.9 \\
\hline & Divorced & 0 & 0 \\
\hline & Widow & 0 & 0 \\
\hline & Total & 106 & 100 \\
\hline \multirow{5}{*}{ Designation } & Teaching Assistant & 4 & 3.8 \\
\hline & Lecturer & 74 & 69.8 \\
\hline & Reader & 24 & 22.6 \\
\hline & Professor & 4 & 3.8 \\
\hline & Total & 106 & 100 \\
\hline \multirow{6}{*}{ Service Year } & $\leq 5$ & 10 & 9.4 \\
\hline & $>5 \leq 10$ & 17 & 16.0 \\
\hline & $>10 \leq 15$ & 43 & 40.6 \\
\hline & $>15 \leq 20$ & 31 & 29.2 \\
\hline & Above 20 & 5 & 4.7 \\
\hline & Total & 106 & 100 \\
\hline \multirow{5}{*}{ Education } & Masters & 22 & 20.8 \\
\hline & M. Phil & 57 & 53.8 \\
\hline & $\mathrm{Ph} . \mathrm{D}$ & 27 & 25.4 \\
\hline & Post- Doctorate & 0 & 0 \\
\hline & Total & 106 & 100 \\
\hline \multirow{7}{*}{ Age } & $\leq 30$ & 0 & 0 \\
\hline & $>30 \leq 35$ & 4 & 3.8 \\
\hline & $>35 \leq 40$ & 31 & 29.2 \\
\hline & $>40 \leq 45$ & 39 & 36.8 \\
\hline & $>45 \leq 50$ & 25 & 23.6 \\
\hline & Above 50 & 7 & 6.6 \\
\hline & Total & 106 & 100 \\
\hline \multirow{3}{*}{ Service Types } & Permanent & 98 & 92.5 \\
\hline & Contract & 8 & 7.5 \\
\hline & Total & 106 & 100 \\
\hline \multirow{3}{*}{ Types of college } & Central & 21 & 19.8 \\
\hline & Constituent & 85 & 80.2 \\
\hline & Total & 106 & 100 \\
\hline \multirow{5}{*}{$\begin{array}{l}\text { Monthly stipend including basic } \\
\text { and extra }\end{array}$} & $\leq 50000$ & 67 & 63.2 \\
\hline & $50001-70000$ & 39 & 36.8 \\
\hline & $70001-90000$ & 0 & 0 \\
\hline & Above 90000 & 0 & 0 \\
\hline & Total & 106 & 100 \\
\hline
\end{tabular}

(Source: Field Survey, 2018) 
Table 1 shows the highest percentage of respondents was male with 98.1 percent as compare to female with 1.9 percent. With regard to marital status of respondents, this study showed that married respondent with highest percentage at 99.1 whereas unmarried was at 0.1 percent.

With regard to designation, the study showed that lecturer with highest percentage at 69.8 percent as compare to reader with 22.6 percent, teaching assistant with 3.8 percent, and professor with 3.8 percent.

Regarding the year of service of respondents in the campus, most of the respondents were $>10 \leq 15$ years at 40.6 percent, whereas $>15 \leq 20$ years at 29.2 percent, $>5 \leq 10$ years at 16.0 percent, $\leq 5$ years at 9.4 percent and above 20 years at 4.7 percent

Regarding the educational level of respondents, study showed that M. Phil. with highest percentage at 53.8 percent, whereas Masters with 20.8 percent and $\mathrm{Ph}$.D. with 25.4 percent.

Regarding the age group of respondents, study showed that respondents were mostly between and $>40 \leq 45$ with 36.8 percent, $>35 \leq 40$ years with 29.2 percent $>45 \leq 50$ years with 23.6 percent, $>30 \leq 35$ with 3.8 percent and above 50 years with 6.6 percent.

Regarding monthly stipend including basic and extra 63.2 percent of respondents had earning of less than or equal to 50000 and 36.8 percent of them had earning between 500001 to 70000 and 80.2 percent respondent were from constituent campus and 19.8 percent from central campus with 92.5 percent permanent and 7.5 percent contract faculties.

\section{Demographic factors influencing on variables of job satisfaction}

Table 2: Demographic factors and variables of job satisfaction

\begin{tabular}{|l|c|c|c|c|c|c|}
\hline \multicolumn{1}{|c|}{ Personality } & $\mathrm{J} 1$ & $\mathrm{~J} 2$ & $\mathrm{~J} 3$ & $\mathrm{~J} 4$ & $\mathrm{~J} 5$ & $\mathrm{~J} 6$ \\
\hline Designation & $\begin{array}{c}\mathrm{F}=3.8215 \\
(0.012)^{*}\end{array}$ & $\begin{array}{c}\mathrm{F}=8.327 \\
(0.000)^{*}\end{array}$ & $\begin{array}{c}\mathrm{F}=3.128 \\
(0.029)^{* *}\end{array}$ & $\begin{array}{c}\mathrm{F}=5.465 \\
(0.002)^{* *}\end{array}$ & $\begin{array}{c}\mathrm{F}=1.862 \\
(0.141)\end{array}$ & $\begin{array}{c}\mathrm{F}=3.373 \\
(0.021)^{* *}\end{array}$ \\
\hline Gender & $\begin{array}{c}\mathrm{t}=0.138 \\
(0.855)\end{array}$ & $\begin{array}{c}\mathrm{t}=1.423 \\
(0.158)\end{array}$ & $\begin{array}{c}\mathrm{t}=2.503 \\
(0.14)\end{array}$ & $\begin{array}{c}\mathrm{t}=1.759 \\
(0.082)\end{array}$ & $\begin{array}{c}\mathrm{t}=2.056 \\
(0.042)^{* *}\end{array}$ & $\begin{array}{c}\mathrm{t}=0.802 \\
(0.425)\end{array}$ \\
\hline Service Year & $\mathrm{F}=5.391$ & $\mathrm{~F}=3.053$ & $\mathrm{~F}=0.796$ \\
$(0.001)^{* *}$ & $(0.020)^{* *}$ & $(0.548)$ & $\begin{array}{c}\mathrm{F}=2.501 \\
(0.047)^{* *}\end{array}$ & $\begin{array}{c}\mathrm{F}=1.896 \\
(0.117)\end{array}$ & $\begin{array}{c}\mathrm{F}=4.154 \\
(0.004)^{* *}\end{array}$ \\
\hline Education & $\mathrm{F}=5.415$ & $\mathrm{~F}=6.041$ & $\mathrm{~F}=2.016$ & $\mathrm{~F}=1.847$ \\
$(0.006)^{* *}$ & $(0.003)^{* *}$ & $(0.138)$ & $\begin{array}{c}\mathrm{F}=1.157 \\
(0.163)\end{array}$ & $\begin{array}{c}\mathrm{F}=1.675 \\
(0.318)\end{array}$ & $(0.192)$ \\
\hline Age & $\mathrm{F}=1.796$ & $\mathrm{~F}=4.503$ & $\mathrm{~F}=0.370$ & $\mathrm{~F}=2.260$ & $\mathrm{~F}=0.920$ & $\mathrm{~F}=2.982$ \\
$(0.135)$ & $(0.002)^{* *}$ & $(0.829)$ & $(0.068)$ & $(0.455)$ & $(0.23)$ \\
\hline Service types & $\begin{array}{c}\mathrm{t}=0.1 .125 \\
(0.263)\end{array}$ & $\begin{array}{c}\mathrm{t}=2.273 \\
(0.025)^{* *}\end{array}$ & $\begin{array}{c}\mathrm{t}=1.789 \\
(0.077)\end{array}$ & $\begin{array}{c}\mathrm{t}=2.514 \\
(0.013)^{* *}\end{array}$ & $\begin{array}{c}\mathrm{t}=1.539 \\
(1.778)\end{array}$ & $\begin{array}{c}\mathrm{t}=0.127 \\
(0.078)\end{array}$ \\
\hline Types of college & $\mathrm{t}=-0.968$ & $\mathrm{t}=1.525$ & $\mathrm{t}=-1.840$ \\
$(0.335)$ & $(0.130)$ & $(0.069)$ & $\begin{array}{c}\mathrm{t}=-0.326 \\
(0.745)\end{array}$ & $\begin{array}{c}\mathrm{t}=0.688 \\
(0.443)\end{array}$ & $\begin{array}{c}\mathrm{t}=-0.105 \\
(0.916)\end{array}$ \\
\hline $\begin{array}{l}\text { Monthly stipend } \\
\text { including basic and } \\
\text { extra }\end{array}$ & $\begin{array}{c}\mathrm{F}=11.386 \\
(0.001)^{* *}\end{array}$ & $\begin{array}{c}\mathrm{F}=18.503 \\
(0.000)^{* *}\end{array}$ & $\begin{array}{c}\mathrm{F}=21.036 \\
(0.000)^{* *}\end{array}$ & $\begin{array}{l}\mathrm{F}=14.396 \\
(0.000)^{* *}\end{array}$ & $\begin{array}{c}\mathrm{F}=15.572 \\
(0.000)^{* *}\end{array}$ & $\begin{array}{c}\mathrm{F}=17.676 \\
(0.000)^{* *}\end{array}$ \\
\hline
\end{tabular}

** means the statistics is significant at $5 \%$ level of significance and values in parenthesis are $\mathrm{p}$ value

Variables representation:

$\mathrm{J} 1=$ social recognition, $\mathrm{J} 2=$ working environment, $\mathrm{J} 3=$ compensation, $\mathrm{J} 4=$ recognition, $\mathrm{J} 5=$ Promotion, and $\mathrm{J} 6=$ Union 
Vol. 4, No. 1

In table 2, ANOVA analysis shows that there is a significant difference in social recognition of faculty members with respect to designation $(\mathrm{p}=0.012<0.05)$, service year $(\mathrm{p}=0.001<0.05)$, education $(\mathrm{p}=0.006<0.05)$ and monthly income $(\mathrm{p}=0.0015<0.05)$ at 0.05 percent level of significance but not with respect to age $(p=0.135>0.05)$. Similarly, $t-$ test shows that there is no significant difference in social recognition of faculty members with respect to gender $(p=0.855>0.05)$, service types $(p=0.335>0.05)$ and types of college $(\mathrm{p}=0.335>0.05)$.

ANOVA analysis shows that there is a significant difference in working environment of university with respect to designation $(\mathrm{p}=0.000<0.05)$, service year $(\mathrm{p}=0.020<0.05)$, education $(\mathrm{p}=0.003<0.05)$, age $(\mathrm{p}=0.002<0.05)$ and monthly income $(\mathrm{p}=0.000<0.05)$ at 0.05 percent level of significance but not with respect to age $(\mathrm{p}=0.135>0.05)$. $\mathrm{t}$ - test shows that there is a significant difference in working environment with respect to service types ( $p=0.025<0.05)$ but not with respect to types of college $(p=0.130>0.05)$, and gender $(\mathrm{p}=0.158>0.05)$.

ANOVA analysis shows that there is a significant difference in compensation package of university with respect to designation $(\mathrm{p}=0.029<0.05)$ and monthly income $(\mathrm{p}=0.000<0.05)$, except service year $(\mathrm{p}=0.548>0.05)$, education $(\mathrm{p}=0.138>0.05)$ and age $(\mathrm{p}=0.8829>0.05)$ at 0.05 level of significance. T-test shows that there is no significant difference in compensation with respect to gender $(\mathrm{p}=0.14>0.05)$, service type $(\mathrm{p}=0.077)$, and types of college $(\mathrm{p}=0.069>0.05)$ at 0.05 level of significance.

ANOVA analysis shows that there is a significant difference in recognition of faculty members with respect to designation ( $\mathrm{p}=0.002<0.05)$, service year $(\mathrm{p}=0.047<0.05)$, and monthly income $(\mathrm{p}=0.000<0.05)$ at 0.05 level of significance but not with respect to education $(\mathrm{p}=0.163>0.05)$ age $(\mathrm{p}=0.068>0.05)$. $\mathrm{t}$ - test shows that there is significant difference in recognition of faculty members with respect to service types $(p=0.013<0.05)$ but not with respect to gender $(p=0.082>0.05)$ and types of college $(p=0.745>0.05)$.

ANOVA analysis shows that there is no significant difference in promotion of faculty members with respect to designation $(p=0.141>0.05)$, service year $(p=0.117>0.05)$, education $(p=0.318>0.05)$ age $(\mathrm{p}=0.455>0.05)$ except monthly income $(\mathrm{p}=0.000<0.05)$ at 0.05 level of significance. $t$ - test shows that there is no significant difference in promotion of faculty members with respect to service types $(p=1.778>0.05)$ and types of college $(p=0.443>0.05)$ except gender $(p=0.042<0.05)$ at 0.05 level of significance.

ANOVA analysis shows that there is a significant difference in union of faculty members with respect to designation $(p=0.042<0.05)$, service year $(p=0.004<0.05)$, monthly income $(p=0.000<0.05)$ except education $(\mathrm{p}=0.192>0.05)$ age $(\mathrm{p}=0.23>0.05)$ at 0.05 level of significance. $\mathrm{t}$ - test shows that there is no significant difference in union of faculty members with respect to service types $(p=0.078>0.05)$ and types of college $(p=0.916>0.05)$ and gender $(p=0.425>0.05)$ at 0.05 level of significance.

\section{Demographic variables and overall job satisfaction of faculty members}

Table 3: Demographic variables and overall job satisfaction

\begin{tabular}{lc}
\hline Variables & Statistical tool \\
\hline Designation and job satisfaction & $\mathrm{F}=5.496\left(\mathrm{p}=0.002^{* *}\right)$ \\
Gender and job satisfaction & $\mathrm{t}=1.873(\mathrm{p}=0.064)$ \\
Service year and job satisfaction & $\mathrm{F}=5.469\left(\mathrm{p}=0.002^{* *}\right)$ \\
Education and job satisfaction & $\mathrm{F}=4.002\left(\mathrm{p}=0.021^{* *}\right)$ \\
Age and job satisfaction & $\mathrm{F}=1.733(\mathrm{p}=0.149)$ \\
Service type and job satisfaction & $\mathrm{t}=2.294\left(\mathrm{p}=0.023^{* *}\right)$ \\
Types of college and job satisfaction & $\mathrm{t}=0.293(\mathrm{p}=0.590)$ \\
Monthly stipend including basic and extra & $\mathrm{F}=27.98\left(\mathrm{p}=0.000^{* *}\right)$ \\
\hline
\end{tabular}

** means the statistics is significant at $5 \%$ level of significance

Table 3 shows that designation $(p=0.002<0.05)$, service year $(p=0.002<0.05)$, education $\sim 65 \sim$ 
$(p=0.021<0.05)$, service type $(p=0.023<0.05)$ and monthly income $(p=0.000<0.005)$ of faculty members have influence on overall job satisfaction at 0.05 level of significance. Gender $(\mathrm{p}=0.064>0.05)$, age $(0.149>0.05)$, and types of college $(0.590>0.05)$ do not have any influence on overall job satisfaction of faculty members.

\section{Conclusions}

The result of the study concluded that among eight demographic variables (designation, age, gender service year, education, income, service type, type of college), monthly income seemed more important variable which had significant influence on six variables (social recognition, working environment, compensation, promotion recognition and union) of job satisfaction. Furthermore, designation seemed second important demographic variable which had significant influence on five variables of job satisfaction of faculty members. Variable like type of college did not seem any important demographic variable which did not show any influence on any element of job satisfaction. While analyzing influence of demographic variables on overall job satisfaction, designation, service type, service year, education and income of faculty members showed influence on overall job satisfaction whereas gender, age, type of college did not show any influence.

It is clear that the demographic profile of university faculty member affect effectiveness of university indirectly by influencing on job satisfaction. It is therefore suggested that demographic factors of faculty members be recognized and appreciated fully for their contribution to enhance organizational growth and development. University is recommended to ensure individual customization of work load and performance reward structures, as well as characteristics of the work environment, based on demographic profile. The review of the literature on the influence of demographic variables on job satisfaction has shown that the findings are mixed. These incongruences call for future researcher to add to the literature. Researcher also calls for future researcher to cover the sample from other university of Nepal to provide comprehended result related to factors that influence job satisfaction of faculty members.

\section{References}

Amarasena et al. (2015). The effect of demographic factors on job satisfaction of university faculty members in Shri Lanka. International Journal of Academic Research and Reflection, 3(4), 89-106.

Amarasena, T. S. M., Ajward, A.R., \& Haque,A. K. M(2015). Does social impact of job satisfaction of academy faculty members of state university of Sri Lanka. International Journal of Recent Advances in Organizational Behavior and Decision sciences, 4(1), 540-553.

Asmani, L., \& Menesh, A. O. (2013). The effect of unionization on employees' job satisfaction and organizational commitment in the Cape Coast Takoradi Metropolis of Ghana. European Journal of business and Management, 5(19), 186-195.

Awang, Z., Hanim, J. H., \& Mohammed, N. Z. (2010). Modeling job satisfaction and work commitment among lecturers. Journal of Statistical Modeling and Analytic, 1(2), 45-59.

Danish, R., \& Usman, A. (2010). Impact of Reward and Recognition on Job Satisfaction and Motivation: An Empirical Study from Pakistan. International Journal of Business and Management, 5(2), 167-195.

Joasias, B. A. (2005). The relationship between job satisfaction and absenteeism in a selected field services within electricity utility in the Western Cape. Yukese Lisan Tezi. Western Cape 
Vol. 4, No. 1

University. Faculty of Management and Sciences.

Jorfi, H., Yaccob, H. F \& Shah, I. M. (2011). The relationship between demographics variables, emotional intelligence, communication effectiveness, motivation and job satisfaction. International Journal of Academic Research in Business and Social Science, 1(1), 35-58.

Kaliski, B. S. (2007). Encyclopedia of Business and Finance.

Milledzi, E.Y., Amponsah, M. D.,and Asamani (2018). Impact of socio-demographic factors on job satisfaction among academic staff of universities Ghana. International Journal of Research Studies in Education, 7(2), 67-88.

Nunnally, J. C. and Bernstein, I. H. (1994). The Assessment of Reliability. Psychometric Theory, 3, 248-292.

Paul, E. P., \& Phua, S. K. (2011). Lecturers' job satisfaction in a public tertiary institution in Singapore: ambivalent and non-ambivalent relationships between job satisfaction and demographic variables. Journal of Higher Education Policy and Management, 33(2), 141151.

Pfeffer, A., \& Davis, A. B. (1990). Unions and job satisfaction: an alternative view. Sage Journal, 17(3), 259-282.

Saane, N. V., Sluiter, J., Verbeek, J., \& Frings, D. M. (2003). Reliability and validity of instruments measuring job satisfaction - a systematic review. Occupational Medicine, 53, 119-200.

Sseganga, K., \& Garrett, R. M. (2005). Job satisfaction of university academics: Perspectives from Uganda. Higher Education, 50 (1), 33-56.

Strydom, A. (2011). The Job Satisfaction of Academic Staff Members on Fixed-Term Employment Contracts at South African Higher Education Institutes. University of the Free State Faculty of Education.

Tribhuvan University. (2018, May 11). Introduction. Retrieved from https://ribhuvan-university. edu.np/

Vandenberghe, C., \& Trembley, M. (2008). The Role of Pay Satisfaction and Organizational Commitment in Turnover Intention: A Two Sample Study. Journal of Business Psychology, $22(3), 275-286$.

Zainudin, A., Junaidah, H. A., \& Nazmi, M. Z. (2010). Modelling job satisfaction and work commitment among lecturers: a case of UITM Kelantan. Journal of Statistical Modeling and Analytics, 1(2), 45-59.

Zarafshani, K. \& Alibaygi, A. (2008). Predictors of job satisfaction among academic in Iranian University, NACTA Journal, 104(2), 633-644. 